\title{
Abuse of the Religious Sentiment to Gain Political Purpose in Bangladesh
}

\author{
Md. Iftakharul Islam ${ }^{1}$, Kaniz Marzia ${ }^{2}$
}

\begin{abstract}
Religion did play a major role in the way the map of India and Pakistan was drawn then. It is believed that the seed of the birth of Bangladesh was sown then. As Bangladesh had witnessed the outcome of religion based statehood, therefore, religious secularism was one of the fundamentals of the constitution of Bangladesh. This however, changed with an amendment in 1977 where the term 'absolute trust and faith in the Almighty Allah' was incorporated instead of the principle of secularism. It may have seemed that secularism was a logical outcome of the Bengali nationalist movement but the new nation-state had within its construction the quest for homogenization. Finally, through the Constitution (Fifteenth Amendment) Act, 2011 the Preamble of the Constitution included the fundamental principles of democracy, socialism, secularism and nationalism, earlier adopted by the Constituent Assembly in 1972, have been revived. Equal status and equal right in practice of the followers of the Hindu, Muslim, Buddhist, Christian and other religions have been ensured. Over the last two decades of the formation of democratic regime we are still struggling to epitomize our identity as a nation and the duty lies upon the society more than on politicians to rejuvenate our basic ideologies by way of eschewing pseudo-religious vendetta for a better democracy.
\end{abstract}

Keywords: Democracy, Fundamentalism, Incorporation, Independence, Politics, Religion \& Secularism

\section{Introduction}

The simultaneous presence of religion and politics is an age old phenomenon of human history. In all regions, including South Asia, America and Europe, over time we see this presence. The influence of religion in politics, on culture and societal behaviors cannot be underestimated. The People's Republic of Bangladesh is located in the South Asian region. Geographically it is almost totally surrounded by India, except for a border with Myanmar on southeast and southern coastline on the Bay of Bengal. The country covers an area of $1,47,570$ square kilometers and has a tropical climate ${ }^{3}$. Religion has played a prominent role in Bangladesh's political history over decades. After gaining independence from Pakistan in 1971, the Bangladesh Awami League was founded under the guiding principle of secularism. However, power shifts among the One Party Political System, Military, Bangladesh Nationalist Party and Jatio Party throughout the 1974s to 1990s resulted in religion being added to the constitution and declared the official state religion. Though still officially on the books today, the current government defines the country as "secular with a majority Muslim population," and not officially as a Muslim state.

\section{Definition of Religion}

A set of beliefs concerning the cause, nature, and purpose of the universe, especially when considered as the creation of a superhuman agency or agencies, usually involving devotional and ritual observances, and often containing a moral code governing the conduct of human affairs. Belief in and reverence for a supernatural power is regarded as creator and governor of the universe. Religion has always been a strong part of social identity, but this has varied at different times. A survey in late 2003 confirmed that religion is the first choice by a citizen for self-identification. According to a government published article, atheism is extremely rare ${ }^{4}$.

\footnotetext{
${ }^{1}$ Lecturer, Department of Law, Northern University Bangladesh

${ }^{2}$ BSS \& MSS, Department of Political Science, University of Dhaka, Bangladesh

${ }^{3}$ (Ahmed, 1964: 29), Ahmad, A. (1964) Studies in Islamic Culture in the Indian Environment. Oxford: Clarendon Press

${ }^{4}$ Bangladesh, International Religious Freedom Report 2005 Bureau of Democracy, Human Rights, and Labor
} 


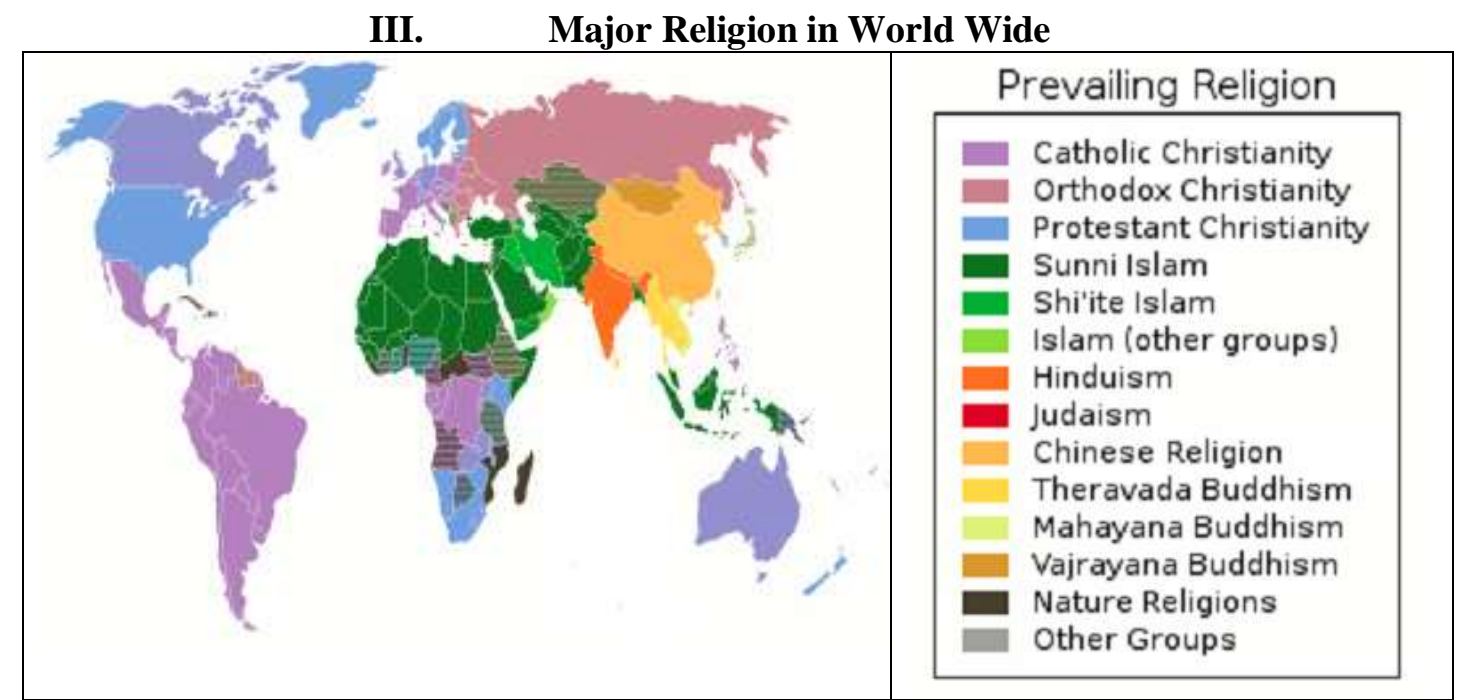

Source:_http://en.wikipedia.org/wiki/Image:Weltreligionen.png and translated into English

\section{Religion and Politics: Nexus}

Religion and religio-political forces have become potent influences in the domestic politics of many countries irrespective of geographical location, stages of economic growth, and systems of governance. The growing importance of religion as a marker of identity and a tool of political mobilization is reshaping the political landscape in an unprecedented manner, and South Asia, which contains the world's largest populations of Muslims and Hindus with significant number of Buddhists, is no exception to this fact.

"The presence and influence of the religious-political parties are the most obvious indicators of the use of religion as a political ideology, but should not be the only indices in measuring the scope and depth of religion's role in society and politics. Understanding the interplay of religion and politics warrants further exploration, particularly the role of the state and the society.

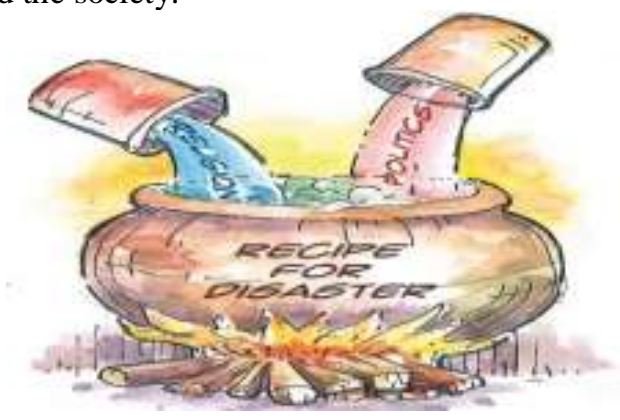

The adoption of a state religion, as in the case of Nepal in 1959, Pakistan in 1972, Bangladesh in 1977 and/or granting a special significance to one religion, as in the constitution in Sri Lanka in 1972, are testimony to religion's political role. The religion becomes a potent political ideology. There are many factors, both domestic and international ${ }^{, 5}$.

- Firstly, historical antecedents

- Secondly, the abject failure of secular liberal states in South Asia. As in many other parts of the world, most of the South Asian states have terrible track records in terms of delivering developmental goods and services. These failures have delegitimized the states and the ruling blocs. This engendered an environment within which religion has appeared as both an ideology of the ruling class and as a counter-hegemonic project. On the one hand, the ruling elites have used various means to continue their hold over power including use of religion (General Ershad's decision to declare Islam the state religion is an example), while on the other hand religio-political forces attempt to demonstrate that failure is inherently connected to the secularist liberal ideology.

- Thirdly, it has to do with globalization, particularly the pace of globalization. The appeal of religious identity is a result of ontological insecurity and existential uncertainty faced by individuals as a result of the pace and nature of globalization in recent decades.

5 (Volume-9, Issue-4, January 22, 2010, the Star, Weekly Publication of the Daily Star 


\section{Religion and Politics: Bangladesh Perspective}

Bangladesh rests on a set of primordial socio-cultural, linguistic and religious identities that have been distinctively shaped by the history of the Bengal delta. The socio-economic system around which modern civilization has grown up in Bengal is derived from a distinctive cultural-religious ideology. As a result, relatively flexible religious ideologies were mobilized around the mode of production and economic life of the people. Subsequent attempts to construct a unique linguistic or religious identity within Bangladesh have tended to ignore the multiple identities around issues of language, class and profession, and this has occasionally served to provoke confrontation and violence.

\begin{tabular}{|l|lll} 
Religious Population & \multicolumn{3}{l}{$\begin{array}{l}\text { Population Population } \\
\text { 6 }\end{array}$} \\
group & $\mathbf{\%} 1975$ & $\mathbf{\%} 1990$ & $\mathbf{\%} 2010$ \\
\hline Muslim & $84 \%$ & $87 \%$ & $89.5 \%$ \\
\hline Hindu & $15.6 \%$ & $12.4 \%$ & $9.5 \%$ \\
\hline Christian & $0.1 \%$ & $0.1 \%$ & $0.3 \%$ \\
\hline Buddhist & $0.3 \%$ & $0.5 \%$ & $0.7 \%$
\end{tabular}

\section{Briefing about the Historical Development of Religion in Bangladesh}

The debate on state and religion became an issue when the 1972 Constitution of Bangladesh stated that secularism was the fourth pillar of state policy. The idea of making secularism part of state policy followed logically from the freedom struggle in which Bengalis sought to establish a democratic country based on secular values.

The essential strength of a secular society is that it reduces the significance of primordial factors such as religion, ethnicity, and caste within national identity construction, influencing political choice and delineating economic opportunities. Article 38 of Bangladesh's Constitution prohibits politics based on religion.

Under this provision, religious parties were banned. After 1975 military regime began to consolidate state power by harping back to issues of religion. In the process of consolidating his political power base, took the steps that began to transform Bengali culture and polity along more communal lines. Religious politics took shape in Bangladesh, with the amendment of Article 38 of the Constitution. The word 'secularism' was deleted, and a new provision incorporated 'to place full Faith in Almighty Allah', by amending article 8(1) of the Constitution. It had also introduced the words 'Bismillahir Rahamnur Rahim' at the top of the preamble. The 'struggle for national Liberation' was replaced by the 'war for national Independence'. Socialism was redesigned to conform to the Islamic idea of social justice. A new clause was added to Article 25(2) relating to' Islamic solidarity', the military regime therefore rejected linguistic nationalism in favour of a territorial Islamic nationalism. The process of Islamisation served the purpose of trying to avert a legitimacy crisis in the face of a weakening economy and persistence of mass poverty. This eventually opened the floodgates for other leaders, such as General H.M. Ershad during the 1980s, to continue using religion as a tool for political purposes. While there is no doubt that Islam was used politically by these leaders, the critical issue is to understand how deeply this 'Islamisation' process has in fact gone. Finally, through the Constitution (Fifteenth Amendment) Act, 2011 the Preamble of the Constitution included the fundamental principles of democracy, socialism, secularism and nationalism, earlier adopted by the Constituent Assembly in 1972, have been revived.

\section{Characteristics of Religion and Politics in Bangladesh}

Bangladesh is reported to have one of the biggest Muslim communities in the world. It was during the 13th century that masses began converting to Islam and this conversion continued for several centuries. It was the Muslim missionaries and mystics who brought the religion of Islam to the people of Bangladesh.

\section{Constitutional Basis of Religion in Bangladesh}

Religious pluralism is a golden thread running through the Constitution that was adopted on November 4, 19727. The concept of freedom of religion is further stipulated in Article 41 of the Constitution, which is as follows:

"(1) Subject to law, public order and morality :( a) every citizen has the right to profess, practice or propagate any religion; (b) every religious community or denomination has the right to establish, maintain, and manage its religious institutions

\footnotetext{
${ }^{6}$ Census Report of Bangladesh

${ }^{7}$ Wednesday, July 20, 2011.Daily Star, Religion-based political parties and the Bangladesh Constitution
} 
(2) No person attending any educational institution shall be required to receive religious instruction, or to take part in or to attend any religious ceremony or worship, if that instruction, ceremony or worship relates to a religion other than this own

Article 41 is founded upon on religious pluralism. In Bangladesh, people of various faiths are deeply religious, and the most devoutly religious people are also the staunchest defenders of religious pluralism ${ }^{8}$.

\section{The Rise of Religious Politics: The Politics of Control}

The wake of Islamist politics in Bangladesh have emerged in the wake of three processes: (1) economic crisis, including the uneven process of development and distribution of advantages between groups and classes; (2) a crisis of political legitimacy, previously a decline in popular support for the religious groups and now for the state; and (3) changes in traditional patriarchal system, with the growing visibility and the public participation of women. While it is highly doubtful that the fundamentalists will be able to achieve their goals, it is probable that we will see continued violence by frustrated activists. In the absence of fully developed, socially rooted, and credible social alternatives, the fundamentalists will continue to pose a threat.

\section{Politicized of Religious Sentiment}

Islam being the central component of national identity plays a significant role in the politics, life and culture of the people. Secular parties such as Awami League also mention "Allah is Great" as a slogan in their banners. When in June 1988 an "Islamic way of life" was proclaimed for Bangladesh by constitutional amendment, very little attention was paid outside the intellectual class to the meaning and impact of such an important national commitment. Most observers believed that the declaration of Islam as the state religion might have a significant impact on national life. However, aside from arousing the suspicion of the non-Islamic minorities, it could accelerate the proliferation of religious parties at both the national and the local levels, thereby exacerbating tension and conflict between secular and religious politicians. Unrest of this nature was reported on some college campuses soon after the amendment was promulgated.

\section{The Growth of Religion Based Politics}

A key change was that in the government of 2001-6, fundamentalist forces had increasingly begun to occupy legitimate political space as the ideals of the Liberation movement faded and the re-emergence of Islam as a factor considered necessary to consolidate political power in Bangladesh.The rise of Islamic extremism was fuelled by continuing economic underdevelopment, poverty and unemployment. Bangladesh remains predominantly an agriculture-based society, with more than forty per cent population is still below poverty line. Unemployed immigrants such as Rohinga refugees were systematically targeted and taken advantage of by religious fundamentalist forces. These domestic factors, and the influence of international Islamic actors, both provided a rationale for exploiting illiterate and unemployed youth to promote Islamic extremism, including within an expanding Madrasa sector. The factors beyond Islamic revivalism and intolerance in Bangladesh lie mainly within macro, meso and micro layers of within Bangladesh society and polity. At the macro level, the socio-political elites of the society have used Islamism for political purposes to hold state power and divert from problems of mass poverty and unemployment. In this process, external actors, using petro-dollars from Middle East countries, have imposed their version of Islamism through the work of charities to strengthen a Madrasa culture and patronize mosques ${ }^{9}$.

XII.

Religion Based Political Parties

\begin{tabular}{|c|c|c|c|c|c|}
\hline $\begin{array}{c}\text { Bangladesh } \\
\text { Jamaat-e-Islami: }\end{array}$ & $\begin{array}{l}\text { Bangladesh } \\
\text { Islami Front }\end{array}$ & $\begin{array}{c}\text { Bangladesh } \\
\text { Khilafat Majlis }\end{array}$ & $\begin{array}{l}\text { Islami Oikya } \\
\text { Jote }\end{array}$ & $\begin{array}{l}\text { Islamic Front } \\
\text { Bangladesh }\end{array}$ & $\begin{array}{l}\text { Bangladesh } \\
\text { Khilafat } \\
\text { Andolan } \\
\text { (Bangladesh } \\
\text { Caliphate } \\
\text { Movement) }\end{array}$ \\
\hline $\begin{array}{l}\text { The Jamaat was, } \\
\text { from the } \\
\text { beginning, } \\
\text { inspired by the } \\
\text { Ikhwan ul- } \\
\text { Muslimeen or the } \\
\text { Muslim }\end{array}$ & $\begin{array}{l}\text { The party } \\
\text { launched } 16 \\
\text { candidates. } \\
\text { Together } \\
\text { they } \\
\text { gathered } \\
29,002 \text { votes }\end{array}$ & $\begin{array}{l}\text { The Khilafat } \\
\text { Majlis was } \\
\text { founded in } 1989 \\
\text { is an Islamist } \\
\text { political party } \\
\text { working to } \\
\text { establish an }\end{array}$ & $\begin{array}{l}\text { Led by Ameer } \\
\text { Allama Mufti } \\
\text { Fazlul Huq } \\
\text { Amini and } \\
\text { Chairman } \\
\text { Shaikul Hadith } \\
\text { Allama Azizul }\end{array}$ & $\begin{array}{l}\text { The goal of } \\
\text { the party is the } \\
\text { creation of a } \\
\text { society based } \\
\text { on Sunni } \\
\text { philosophy. It } \\
\text { considers that }\end{array}$ & $\begin{array}{l}\text { It is a Islamist } \\
\text { political party } \\
\text { in Bangladesh, } \\
\text { founded by } \\
\text { Hafezzi Huzur } \\
\text { after the } 1981 \\
\text { presidential }\end{array}$ \\
\hline
\end{tabular}

${ }^{8}$ The constitution of The People's Republic of Bangladesh
9 "Share of Votes by Party". Bangladesh Election Commission 


\begin{tabular}{|c|c|c|c|c|c|c|c|}
\hline $\begin{array}{l}\text { Brotherhood, } \\
\text { which was set up } \\
\text { in Egypt in } 1928 \\
\text { with the aim of } \\
\text { bringing about an } \\
\text { Islamic revolution } \\
\text { and creating an } \\
\text { Islamic state }^{10} \text {. } \\
\text { Bangladesh } \\
\text { Islamic } \\
\text { Assembly), } \\
\text { previously known } \\
\text { as Jamaat-e- } \\
\text { Islami } \\
\text { Bangladesh }\end{array}$ & $\begin{array}{l}(0.05 \% \text { of } \\
\text { the national } \\
\text { vote), but no } \\
\text { seats were } \\
\text { won by the } \\
\text { party }{ }^{12} \text {. }\end{array}$ & $\begin{array}{l}\text { Islamic state } \\
\text { along the lines } \\
\text { of a Caliphate } \\
\text { ('Khilafat') in the } \\
\text { People's } \\
\text { Republic of } \\
\text { Bangladesh. }\end{array}$ & \multicolumn{2}{|c|}{$\begin{array}{l}\text { Haq } \\
\text { connection } \\
\text { with taliban } \\
\text { claimed. . }\end{array}$} & \multicolumn{2}{|c|}{$\begin{array}{l}\text { the main } \\
\text { Islamist party } \\
\text { in Bangladesh, } \\
\text { Bangladesh } \\
\text { Jamaat-e- } \\
\text { Islami, is } \\
\text { distorting } \\
\text { Islam. }\end{array}$} & $\begin{array}{l}\text { electi } \\
1981 \\
\text { third, } \\
3872 \\
(1.79\end{array}$ \\
\hline Election & \multicolumn{3}{|c|}{ Islamic Party } & & $\begin{array}{l}\text { entage of } \\
\text { Joters }\end{array}$ & \multicolumn{2}{|c|}{$\begin{array}{l}\text { Percent } \\
\text { Votes }\end{array}$} \\
\hline 1979 & \multicolumn{3}{|c|}{$\begin{array}{l}\text { Muslim League \& IslamicDemocratic } \\
\text { League (IDLR) }\end{array}$} & & - & \multicolumn{2}{|c|}{6.7} \\
\hline 1986 & \multicolumn{3}{|c|}{ Muslim League } & & - & \multicolumn{2}{|c|}{1.6} \\
\hline 1986 & \multicolumn{3}{|c|}{ Jamaat-e-Islami } & & 4.6 & \multirow{2}{*}{\multicolumn{2}{|c|}{3.3}} \\
\hline 1991 & \multicolumn{3}{|c|}{ Islami Oikkya Jote (Islamic Unity Front) } & & 0.8 & & 0.3 \\
\hline 1991 & \multicolumn{3}{|c|}{ Jamaat-e-Islami (Islamic Society) } & & 12.1 & \multicolumn{2}{|c|}{6.0} \\
\hline 1996 & \multirow{2}{*}{\multicolumn{3}{|c|}{$\begin{array}{l}\text { Islami Oikkya Jote(Islamic Unity Front) } \\
\text { Jamaat-e-Islami (Islamic Society) }\end{array}$}} & & 1.1 & \multicolumn{2}{|c|}{0.3} \\
\hline 1996 & & & & & 8.6 & \multicolumn{2}{|c|}{1.0} \\
\hline 2001 & \multirow{2}{*}{\multicolumn{3}{|c|}{$\begin{array}{l}\text { SSlami Oikkya Jote(ISlamic Unity Front) } \\
\text { Jamaat-e-Islami (IslamicSociety) }\end{array}$}} & & 0.7 & \multicolumn{2}{|c|}{0.7} \\
\hline 2001 & & & & & 4.3 & \multirow{2}{*}{\multicolumn{2}{|c|}{5.7}} \\
\hline 2008 & \multicolumn{3}{|c|}{ Islami Oikkya Jote(Islamic Unity Front) } & & 0.0 & & \\
\hline
\end{tabular}

\section{Religion in Politics and its Transition to Extremism}

Religious extremism and its role in Bangladeshi politics is visible not just in the countryside but in urban areas as well. Political Islam of the 1970s seems to be paying dividends. Bangladesh is experiencing the influx of alumni from the estimated 64,000 madrassas in Bangladesh ${ }^{14}$. In addition to that several other radical groups are getting legitimacy due to close alliance with the largest political party which formed government in coalition with Religious political party in the 2001 election. Although these religious parties were not as strong as in Pakistan or in India, yet their inclusion in government was a change towards that end. This has indirectly strengthened the radical groups to act with freedom.

\section{XIV. $\quad$ Status of Religious Freedom}

Family laws concerning marriage, divorce, and adoption differ depending on the religion of the person involved. There is also, Anglo-Indian Civil Law in some of these regards in parallel. There are no legal restrictions on marriage between members of different faiths but to get marriage registered under Muslim religious laws, the bride and the bride-groom must be Muslims by birth or by conversion. There are approximately 100,000 Ahmadis concentrated in Dhaka and several other locales. While mainstream Muslims rejected some of the Ahmadiyya teachings, the majority supported Ahmadis right to practice without fear of persecution. However, Ahmadis are continued to be subjected to harassment and violence from those who denounced their teachings.

\footnotetext{
${ }^{10}$ Ahmed Rashid, Taliban: The Story of the Afghan Warlords, London: Pan Books, 2001, p. 89.

${ }^{11}$ The Daily New Nation, October 21, 2008

12 "Bangladesh Today", International Crisis Group, Asia Report 121, October 23, 2006.

${ }_{13}$ Ahamed, Emajuddin; D. R. J. A. Nazneen (Aug 1990). "Islam in Bangladesh: Revivalism or Power Politics?" Asian Survey 30 (8): 802

14 Alok Kumar Gupta and Sarswati Chanda, "Islamic Fundamentalism in Bangladesh and Pakistan: Role of Madrassas", IPCS , New Delhi, article \# 753, 21 May 2002,
} 


\section{Targeting Minorities and Using Religion}

As a result of this inhuman religious discrimination, minorities are losing their lives and properties. After the formation of independent Bangladesh in 1971, the Government grabbed Hindu land with the help of the so called "Vested Property Act". Though the said black Act was repealed later on, the minorities did not get back their land snatched away by the Government. By a verdict in 2001, the Bangladeshi Supreme Court had directed the government to return the land, grabbed with the help of the said black Act, to the real owner. In spite of that, few Hindus could get back their land ${ }^{15}$

$>$ Abuses of Religious Freedom

> Forced Religious Conversion: There were no reports of forced religious conversion, including of minor U.S. citizens who had been abducted or illegally removed from the United States, or of the refusal to allow such citizens to be returned to the United States.

$>$ Abuses by Terrorist Organizations

$>$ Attacks on minorities.

\section{Societal Feedbacks Towards Ongoing Structure}

Politics of Religion and Distortion of Ideologies: Politics of religion becomes a component of nasty politics without having any ideology rather than the whim of capturing power.

\begin{tabular}{cc}
\multicolumn{2}{c}{ Decreasing Number of Minorities ${ }^{\mathbf{1 6}}$} \\
Declining Hindu population in Bangladesh region \\
Year & Percentage (\%) \\
$\mathbf{1 9 4 1}$ & 28.0 \\
$\mathbf{1 9 5 1}$ & 22.0 \\
$\mathbf{1 9 6 1}$ & 18.5 \\
$\mathbf{1 9 7 4}$ & 13.5 \\
$\mathbf{1 9 8 1}$ & 12.13 \\
$\mathbf{1 9 9 1}$ & 11.62 \\
$\mathbf{2 0 0 1}$ & 9.2
\end{tabular}

Sabotage among Societies: Mistrust among communities has been built up because of this type of disruption which makes sabotage to breach harmony in society.

Religious Extremism: Regions extremism is the grooming place of having such societal condition which speeded the frequent attack JMB and such other organization.

Security Crisis among Minority: In the last three decades, human rights abuses against the Hindu minority in Bangladesh have largely gone unreported. Bangladeshi nationalism has failed to accommodate the Hindu minority. The continuance of the Enemy Property (Custody and Registration) Order II of 1965 of the then East Pakistan Government albeit, under a new name, stands testimony to the less than equal status of the Hindu citizen in Bangladesh. The order identified minority Hindus as enemies and it was used as an instrument to take away land from them who were conveniently labeled as supporters of India. The Hindus flee from Bangladesh to neighboring India after the Government grabs their lands. When people lose their lands, they lose their livelihood. It affects their social security, health, education, standard of living and religious freedom. The Hindus are immediately beset by poverty. It is evident that the present Government in Bangladesh has neither the political will nor the space to effect the necessary changes in discriminatory laws.

\section{Behavior of Politics Towards Minorities}

Despite their dwindling numbers, Hindus still yield considerable influence because of their geographical concentration in certain regions. They form a majority of the electorate in at least two parliamentary constituencies (Khulna-1 and Gopalganj-3) and account for more than 25\% in at least another twenty. For this reason, they are often the deciding factor in parliamentary elections where victory margins can be extremely narrow. It is also frequently alleged that this is a prime reason for many Hindus being prevented from voting in elections, either through intimidating actual voters, or through exclusion in voter list revisions ${ }^{17}$.

15 Non-Muslim Minorities in Bangladesh: Victim of Bloody Religious Persecution by Dr Radhasyam Brahmachari,30 May, 2008,Daily Star) 16 Source: Census of India 1941, Census of East Pakistan, Bangladesh Government Census

17 Daily Star, January 4, 2006). 


\section{Consequences of Imposing Extreme Limitation}

In real life, when a tree is planted and it is tender we can easily uproot it because the roots are fragile and shallow. But on the contrary, if the tree gradually becomes matured day by day, it sends its root deep-down and it grows into so many branches that we cannot uproot it easily. Moreover, time and environment make the job literally impossible. Though the tree can be cut down but it is impossible uproot it in total unit. According to the above mentioned example, hypothetically, it is impossible to uproot all the religious political parties. Though officially it is possible to ban all the religious political parties, to stop all their political activities is a major obstacle and real challenge for the government. If those religious political parties still run their activities, the country will heavily experience anarchy and chaos. It will ultimately lead every citizen to a threat and social security will be degraded. As a result, the whole country's socio-economic, political and cultural sectors will be badly affected. But still the flicker of hope appears in the sense that if the government bans the use of religious sentiment in political sphere without banning any political party, if the government passes a law restraining religious sentiment while doing politics, it will bring a fresh turn over the political scenario of Bangladesh.

XIX. Recommendations

$>$ Ensuring constitutional rights of every community

$>$ Social Justice

$>$ Grassroots leadership

$>$ Increasing Minority quota

$>$ Special representation of minority

$>$ Establishing democratic feeling among citizens about other religion etc.

XX. Concluding Remarks

It is important to note that the religious element has always been present, though it was not so dominant in Bangladesh culture. It's a matter of debate though that Islam did not play its political role because of the unique socio-political developments in East Pakistan, especially during the period of 1947-1971 ${ }^{18}$. But in the phase of time many changes have shaped the societal structure of Bangladesh and intermingled religion and politics. Religion and politics are like oil and water; if allowed to mix create a dangerous situation under certain conditions. Religion should not be allowed to mingle with politics because such mixing might engender a dire future for country such as Bangladesh.

${ }^{18}$ U. A. B. Razia Akter Banu, Islam in Bangladesh (Leiden: E. J. Brill, 1992), 183. 